\title{
Invited commentary: The Covid-19 pandemic in the United States
}

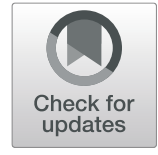

Neil A. (Tony) Holtzman

\begin{abstract}
Despite being the wealthiest and one of the most technologically advanced countries in the world, the United States has the greatest number of Covid-19 cases and deaths. What accounts for this failure? The dismantling of the country's public health infrastructure has crippled contact tracing and exacerbated inequality as a disproportionate number of poor people and people of color have fallen ill with Covid-19. Inadequate regulation of the private forprofit sector has adversely affected the efficiency and quality of testing for the virus, and the prescription of costly drugs whose benefit and safety in treating infected patients have not been established. More stringent regulation of the commercial sector has led to the development of efficacious vaccines in a remarkably short time. Still, questions remain about the vaccines' effectiveness in the real world, and their safety.
\end{abstract}

In December 2020, the United States had the most cases of, and deaths from, Covid-19 among the 220 countries that report data; the fourth most cases per capita; and the eighth most deaths per capita [1]. ${ }^{1}$ How could the wealthiest and one of the most technologically advanced countries in the world fare so poorly?

President Donald Trump's pursuit of reelection shaped his approach to the pandemic: he willfully and repeatedly denied the severity of the pandemic, and disparaged face masks and safe distancing. Had not many state, city, and county officials insisted on masks and restricted public events and business openings, the toll would have been higher. Believing that restoring jobs would gain him votes, Trump ignored public health authorities' warning that reopening society before containing the pandemic would cause a resurgence of Covid-19. With some reopening, the unemployment rate did fall from a high of $14.7 \%$ in April 2020 to $6.7 \%$ in November but close to 11 million people remained unemployed [2], the

\footnotetext{
${ }^{1}$ Deaths per capita in countries with total populations over 1 million. As of 17 December 2020.
}

Correspondence: nholtzm1@jhu.edu

Johns Hopkins School of Medicine (Emeritus), Baltimore, MD, USA surges have materialized [1], and Trump did not win reelection.

Not surprisingly, Trump's appointments-the Commissioner of the Food and Drug Administration (FDA), the Director of the Centers for Disease Control and Prevention (CDC), his cabinet-and the Republican U.S. Senate majority followed his lead. During Trump's presidency, dismantling of the public health infrastructure and deregulation of the private sector both accelerated. The President and his administration undermined diagnostic testing and contact-tracing, and exacerbated inequality. Vaccine development has fared better. I explore these issues in this commentary.

\section{Dismantling the public health response}

Over the past 15 years, federal funding for public health preparedness has been reduced by $28 \%$ [3]. Between 2008 and 2017, more than 55,000 positions were eliminated from local health departments. Before Covid-19 reached the U.S., President Trump's proposed 2021 budget for the Centers for Disease Control and Prevention (CDC) was $10 \%$ less than the previous year, including a cut of $\$ 85.3$ million in its program for emerging infectious diseases [4]. In 2018, the National Security Council's Global Health Security and Biodefense unit, 
established in 2015 by the Obama Administration after the Ebola outbreak in 2014, was largely disbanded [5].

Judges appointed by a Republican majority in the Senate are also upending a historical tradition of upholding state laws that protected the public's health, including inspection, quarantine, and vaccination [6].

On 15 May the U.S. House of Representatives passed the HEROES Act, ${ }^{2}$ but U.S. Senate Majority Leader McConnell refused to allow the Senate to consider it or a revision the House of Representatives passed on October 1 . If the Senate had passed and the President signed it, the legislation would have enabled state and local health departments to undertake massive contact tracing of SARS-CoV-2, preventing many Covid-19 cases and deaths.

\section{Deregulation: emergency use authorization (EUA)}

First established under President George W. Bush in 2004, the emergency use of diagnostics and therapeutics had its origin in the 1980s. Pressured by gay men who demanded the rapid availability of new drugs to treat HIV-AIDS, the FDA relaxed its stringent regulations amid bitter controversy. The 2004 law permitted the FDA to approve the use of new drugs and diagnostics without meeting its usual requirements in the event of a public health emergency.

The Trump Administration declared such an emergency for Covid-19 on 31 January 2020. On 4 February, FDA issued its first EUA to CDC for its reverse transcriptase-polymerase chain reaction (RT-PCR) test kit to detect the SARS-CoV-2 virus. Remarkably, the EUAs for RT-PCR waived FDA's "good manufacturing practice requirements, including the quality system requirements ... with respect to the design, manufacture, packaging, labeling, storage, and distribution of your product" [7]. The agency went even further at the end of March, announcing that it had "revised the [EUA] process to allow labs to begin testing prior to FDA review of their validation data. This policy change was an unprecedented action to expand access to testing (emphasis added)" [8].

Under its EUA, CDC shipped PCR test kits to public health laboratories "before QC [quality control] had been conducted on them ... (T)his might have compromised sufficient QC ... to identify ... the possibility of contamination before shipment" [9]. Of the 26 health department laboratories to whom CDC delivered RTPCR kits in early February, 24 promptly discovered that the positive control vials in the kits were contaminated

\footnotetext{
${ }^{2}$ In addition to greatly increasing funds to health departments, the HEROES Act extended and supplemented unemployment payments and other benefits of the CARES Act to cope with the pandemic. The CARES Act was passed with bipartisan support by both houses of Congress and signed by President Trump in March 2020.
}

with SARS-CoV-2, yielding false positive test results [10]. By 10 February, CDC recalled the contaminated kits before they had been used to test patients. By 29 February, CDC and state and local health department laboratories were able to provide validated PCR tests.

By early March, FDA began to receive applications for EUAs for diagnostic tests from commercial laboratories and manufacturers, approving the first of them on 12 March. Other approvals quickly followed and by 15 December 2020 FDA had issued 199 EUAs for SARS-CoV2 tests. Most EUAs went to commercial in-house testing laboratories and test-kit manufacturers, with a few to non-profit hospitals and research laboratories as well as to health department laboratories [11]. In previous recent epidemics in the U.S., most if not all diagnostic testing was done in public health department laboratories using CDC test kits.

The low bar to launching a test under an EUA made it easy for organizations with questionable expertise to enter the testing arena. In Utah, Nebraska, Iowa, and Tennessee, evidence of fraud by a testing consortium that had been awarded millions of dollars in state contracts quickly surfaced when it could not deliver the quantity of tests promised or attain the level of validity as tests in other laboratories [12,13].

The ease with which EUAs for SARS-CoV-2 tests could be obtained also stimulated innovations in PCR tests and in antigen tests for the virus's spike protein. However, at the time the first EUAs were issued, a valid PCR test was all that was needed to cope with the pandemic. By opening the floodgates to private investment, the EUAs not only led to corrupt practices and poorly validated tests, but stymied effective contact tracing by public health organizations.

Had the Trump administration given CDC more resources for quality-assured RT-PCR test production so that it and state and local health departments were capable of performing most diagnostic tests in the U.S. rather than opening the field to commercial laboratories and manufacturers, the pandemic could have been quickly contained. The Trump administration also showed its predilection for private industry when it demanded that CDC delete an app from its website that allowed Americans to screen themselves for symptoms of Covid-19. Instead, the administration worked with the Apple corporation to develop a similar tool [14].

FDA also issued EUAs for two drugs to treat Covid-19 patients. Political intrusion was clearly evident in the first, the anti-malarial hydroxychloroquine. FDA issued an EUA for it on 28 March and the Trump Administration promoted even broader distribution of the drug than the EUA authorized. Because of serious adverse events and lack of efficacy, FDA withdrew the EUA in June 2020 [15]. 
The EUA for the second drug, Remdesivir, ended on October 22, when FDA approved its use in Covid-19 patients, the first drug to receive that status. In contrast to FDA's plan to convene an advisory committee before approving vaccines for SARS-CoV-2 (see below), the agency did not convene its Antimicrobial Drugs Advisory Committee before approving Remdesivir although several controlled clinical trials, including a very large one by the World Health Organization, found that at best the drug shortened the duration of mild illness by a few days. It did not consistently reduce the viral load or the chance of death from the infection [16]. Approval could bring its manufacturer, Gilead Sciences, more than $\$ 1$ billion. Gilead's price for a course of Remdesivir therapy for Covid-19 is $\$ 3120$ [17].

On 11 November 2020, FDA granted an EUA to Eli Lilly Co. for a monoclonal antibody against a SARSCoV-2 protein for treating mild to moderate covid-19 but warned that hospitalized Covid-19 patients or those requiring oxygen therapy to whom the drug was administered might have poorer outcomes [18].

\section{Diagnostic testing}

With over 100 laboratories performing diagnostic tests in the U.S., and with the United States second only to China in the total number of tests, and tests per capita ${ }^{3}$ reported for SARS-CoV-2 [1], a shortage of effectively used tests seems an unlikely explanation for why the U.S. remained the country with the most Covid-19 cases and deaths.

The tests were not used effectively. The Atlantic stated the major reason for the U.S. failure to contain the pandemic:

Our reporting has unearthed a new coronavirustesting crisis. Its main cause is not the federal government, nor state public-health labs, but the private companies that now dominate the country's testing capacity. Testing backlogs have ballooned, slowing efficient patient care and delivering a heavily lagged view of the outbreak to decision makers (emphasis added) [19].

Without adequate public health resources, U.S. vulnerability to the virus has been at the mercy of the market.

Test inaccuracies are another factor contributing to the U.S. failure to contain its pandemic. Some false negative test results could have been avoided if FDA had not waived good manufacturing/QC practices. Two independent academic laboratories found that PCR tests for detecting SARS CoV-2 differed by as much as $15 \%$ in

\footnotetext{
${ }^{3}$ Tests per capita in countries with total populations over one hundred million. As of 17 December 2020.
}

the frequency of false negatives [20]. EUA-authorized laboratories also differed in the amount of SARS-CoV-2 they could detect by over one-thousand fold [21]!

On 16 December FDA approved a home test for SARS-CoV-2 that does not require a doctor's prescription. Although an app is required to get the result, the home test may result in undercounts of the number of infections and reduce the effectiveness of contact tracing. The test also costs about $\$ 30$, putting it out of reach of people at great risk of infection [22].

\section{Contact tracing}

Contact tracing ${ }^{4}$ and quarantine initially contained the epidemics in several countries, including China, South Korea, and New Zealand. Unfortunately, neither the CDC nor state health departments had sufficient funds to mount effective contact tracing for Covid-19. Meanwhile, commercial labs, which perform the majority of tests for SARS-CoV-2 in the U.S., have done little contact tracing. With the additional human resources needed it would be very costly and yield virtually no profit to them. Moreover, a recent survey found that "COVID-19 test result times have gotten faster but are still too slow to support broad contact tracing" [23]. The Trump White House scuttled plans to trace contacts of people present at a White House ceremony with President Trump at which he appeared healthy but was infected with the virus [24].

Contact tracing may not be as effective despite the resurgence of Covid-19 as the public has become more restive with business and school closures, and restrictions on travel and large gatherings. As the pandemic progressed, the 30\% gap between the percentage of Americans who were concerned that businesses were opening too quickly (63\%) rather than too slowly (33\%) at the beginning of July shrank to $12 \%$ at the end of August [25]. Post-voting polls on November 3 showed still less of a gap [26].

\section{Inequality}

Another reason the United States has fared so poorly is that the people at greatest risk of being infected by the virus have not been as able to protect themselves from infection as others. As of July 2020, Blacks and Hispanics had respectively 1.9 and 2.8 times the rate of positive SARS-CoV-2 tests as Whites. Blacks and Hispanics also had respectively 3.3 and 4.1 times as many

\footnotetext{
${ }^{4}$ Contact tracing entails systematically contacting infected individuals and interviewing them to identify others with whom they had been in contact while they were infectious. If diagnostic tests for the disease are available, the contacts are tested and quarantined for the duration of the incubation period, regardless of symptoms. (For Covid-19, asymptomatic contacts can be infectious.) Contacts of those whose test results are positive can in turn be tested.
} 
hospitalizations per capita once they were diagnosed and both groups had 2.4 times as many deaths per capita as Whites [23].

The higher rates were not because these groups did not wear masks. Blacks and Hispanics reported higher use of cloth face masks within a week after CDC recommended them on 3 April: Blacks 74.4\%, Hispanics 77.3\%, compared to $54.3 \%$ using cloth masks among nonHispanic Whites [27].

One reason for their higher rates is that many Black and Hispanic people live in overcrowded, low income neighborhoods where it is harder to limit contacts with others. In April, 38\% of people living in neighborhoods in the lowest income quintile spent the entire day at home, compared to $47.1 \%$ living in the highest quintile. Conversely, $12.6 \%$ in the lowest quintile worked outside the home compared to $10.2 \%$ in the highest quintile [28].

Despite their greater chance of contracting Covid-19, Blacks and Hispanics received only 1.2 and 1.1 times as many SARS-CoV-2 tests respectively as whites. Test results took a day longer to be reported to Blacks than to Whites and only $56 \%$ of all those who tested positive reported being notified for contact tracing [23].

COVID-19 has disproportionately affected people who are incarcerated in the U.S. of whom African Americans and Hispanics comprise $56 \%$ but only $32 \%$ of the population [29]. At the beginning of June, the COVID-19 case rate in prisons was 5.5 times higher and the age-adjusted death rate 3 times higher than that of the overall U.S. population. The average daily increase in Covid-19 cases between 1 March 2020 and the beginning of June was $8.3 \%$ in prisons compared to $3.4 \%$ in the general U.S. population [30].

Federal laws require insurers to pay for the cost of testing for most of those with health insurance (including Medicare and Medicaid). For the uninsured in low and middle income groups, the federal government will reimburse for the test, but such users usually have to pay upfront at the time of testing, deterring many people from being tested. In one large study, test prices ranged between $\$ 20$ and $\$ 850$ per test, with a median of $\$ 127$ [31]. Many testing sites across the country required people to be tested in their cars, making it difficult for people using mass transit or coming on foot to be tested. Nor does the federal government reimburse for ancillary services used with testing, such as personal protective coverings for health care workers administering the tests.

Blacks and Hispanics comprise $45 \%$ of essential workers [32] but, as already stated, only $32 \%$ of the population. In April 2020, the U.S. Department of Labor proposed to relieve employers of the obligation to record Covid-19 infections among workers. If this had gone into effect it would have been difficult to establish that the infections were work-related. Even without it, inspections by the Occupational Safety and Health Administration (OSHA) were cursory in industries declared essential. OSHA also reduced the number of inspectors during the emergency. In at least one instance, a meatprocessing plant's director was given a heads-up the day before an "un-formal" inspection. Eventually, two slaughterhouses were minimally fined, one for $\$ 13,494$, the other for $\$ 15,615$, as a result of 12 Covid-19 deaths and 2,000 workers with positive test results. As a former OSHA Chief of Staff told The New Yorker, "These are Black and brown workers. I just don't think this Administration cares about them at all" [33].

While unemployment remains high, average hourly wages have fallen from April to October 2020 [34], but billionaires in the United States saw their net worth rise by almost $\$ 1$ trillion in the first 9 months of the pandemic [35]. Between April and September 2020, 45 of the 50 most valuable publicly traded U.S. companies turned a profit; 27 of the largest 50 had layoffs. Several of the companies that initially pledged not to lay off workers during the pandemic ended up doing so. One of these companies, Salesforce, laid off 1000 workers in $\mathrm{Au}$ gust 2020 while generating $\$ 2.7$ billion in profit during the first 6 months of the pandemic, a 33\% increase over its profits during the same period in 2019 [36].

\section{Vaccines}

Unlike the situation near the start of the Covid-19 pandemic, when RT-PCR - the scientific basis for a valid diagnostic test for the SARS-CoV-2 virus-was available, no single path to a safe and effective vaccine against the virus was known. Thus it made sense for governments to encourage government and private research laboratories to each develop its own approach to manufacturing a vaccine. In May, the Department of Health and Human Services (DHHS) and the Department of Defense established Operation Warp Speed (OWS) with experts

in development, manufacturing, and distribution to work in close coordination. The initial set of ambitious objectives: to deliver tens of millions of doses of a SARS-CoV-2 vaccine - with demonstrated safety and efficacy, and approved or authorized by the FDA for use in the U.S. population - beginning at the end of 2020 and to have as many as 300 million doses of such vaccines available and deployed by mid-2021 ...OWS leverages the full capacity of the U.S. government to ensure that no technical, logistic, or financial hurdles hinder vaccine development or deployment ...OWS is supporting the companies financially and technically to commence process development and scale up manufacturing [37]. 
Instead of issuing EUAs to give companies free rein in vaccine development, as FDA had done for SARS-CoV-2 RT-PCR tests, OWS first established stringent criteria that pharmaceutical companies had to meet in conducting large scale randomized controlled clinical trials and have efficacy outcomes by early 2021. Only then could they apply to FDA for approval to provide their respective vaccines outside an experimental setting. OWS signed contracts (discussed below) with large pharmaceutical companies to develop and distribute their vaccines. Three companies reached phase 3 of their clinical trials over the summer of 2020 and three others were anticipated to begin phase 3 trials by the end of that year. OWS intentionally chose companies that based their vaccines on any one of four promising platform technologies. Two of the three companies farthest along in phase 3 trials (Pfizer and Moderna) used an mRNA platform while the third (AstraZeneca) used a replication-defective live-vector platform [37].

With unprecedented speed, OWS has achieved its goal for 2020. Pfizer [38] and Moderna [39] established that two doses of their respective mRNA vaccines injected a few weeks apart prevent over 90\% of Covid-19 infections in the total population sampled and applied for EUAs for their vaccines. FDA's guidelines for companies applying for EUAs for Covid-19 vaccines are much more stringent than the EUAs it issued for diagnostic tests, containing no waivers and no compromise with quality [40]. Each applicant must continue its clinical trial, and its EUA application must include information on the trial's interim results on safety and efficacy, fact sheets for providers and vaccine recipients, and plans for distribution.

Applications for an EUA has been or will be reviewed by FDA's Vaccines and Related Biological Products Advisory Committee (VRBPAC) before being approved. All voting members of VRBPAC are, by regulation, without industry affiliations [41].

As of this date, Pfizer and Moderna's EUA applications have been reviewed by VRBPAC. In both cases, FDA asked the committee one question: Do the benefits of the company's vaccine exceed the risks? Many media reports interpret the affirmative but not unanimous votes as recommending issuance of the respective EUAs. The VRBPAC's recommendations undoubtedly helped FDA reach its decision-only occasionally does FDA make a decision against the advice of its advisory committeesbut the agency must take factors other than the benefit: risk ratio into consideration.

Several factors could reduce the benefit of a vaccine in the real world compared to its efficacy in randomized controlled clinical trials: [42] (1) The ongoing clinical trials may still not have enough volunteers in minority groups, elderly people, and teenagers to have as much statistical confidence in the vaccines' effectiveness in them as in the sample as a whole. (2) The vaccines may provide only partial immunity, preventing, for instance, more mild than serious cases and deaths, or immunity may not be long-lasting. (3) Not everyone eligible to receive the vaccine will agree to take it. In a recent poll, $59 \%$ of White but only $43 \%$ of Black Americans indicated they would get the vaccine when it is available [43]. (4) Not everyone will have access to the vaccine. Although "(a)ny vaccine ... purchased with US taxpayer dollars will be given to the American people at no cost", [44] distribution problems may delay or ultimately fail to reach all those at risk [45]. (5) Vaccine lots may become inactivated before they can be injected. This is most likely for Pfizer's vaccine which requires storage at -70 degrees Celsius [38], making it impractical in some poor, rural areas [46].

The safety of anti-viral vaccines-as measured by the frequency of serious adverse events-will take longer to establish than efficacy. Already, however, two of the first vaccinees in the U.K. and one in Alaska have suffered anaphylactic reactions and a fourth suffered a typical moderate allergic reaction with eye puffiness and scratchy throat [47]. All were treated promptly and recovered. The patient who developed anaphylaxis in Alaska had no history of previous severe allergic reaction. The two reactions in Alaska were reported through established surveillance modules from the same hospital on the same day, raising questions of whether other hospitals administering the vaccine have failed to report them and whether the two allergic reactions in Alaska may not have been due to the vaccine but to the vaccinator (e.g., her/his perfume or aftershave) or to some material used in preparing the vaccinees for the injection. It is puzzling that no allergic reactions have been reported in the clinical trials.

Although adverse events are likely to occur within 2 months of completing vaccination, they may be too rare to have been observed in the fewer than 100,000 participants in the clinical trials at the time of the first EUA approvals in December. The occurrence of serious side effects, like Guillain-Barre syndrome in about 1 person in 1.5 million vaccinated for the H1N1 influenza virus in 2009 and about 1 in 100,000 in a 1976 H1N1 epidemic [48], could take hundreds of thousands of Covid-19 vaccinations before it would even be suspected and surveillance of millions of vaccinated people before it could be associated with the vaccine.

Although it is likely that the benefits of the Pfizer and Moderna vaccines, will continue to outweigh the risks, continued surveillance is needed. This will be hampered if volunteers in the ongoing blind clinical trials who received placebo rather than vaccine elect to get vaccinated, making it statistically difficult to 
compare the frequency of adverse reactions in the two groups.

As already noted, OWS has funded pharmaceutical companies to develop and deploy their vaccines. Moderna received almost $\$ 1$ billion in April and AstraZeneca received \$1.2 billion for development in May. Although Pfizer declined government support for development of its vaccine [38], DHHS announced in July that Pfizer will receive up to $\$ 1.95$ billion for large-scale manufacturing and distribution of 100 million doses of its vaccine contingent on FDA approval. "The federal government will own the 100 million doses of vaccine initially produced as a result of this agreement" [44]. In August, DHHS announced \$1.5 billion to support large-scale manufacturing and distribution of Moderna's vaccine, stating that it will own the resulting 100 million doses of vaccine Moderna produces [44]. In December, DHHS signed an agreement with Moderna for an additional 100 million doses and bringing total support for Moderna's distribution to $\$ 4.1$ billion. DHHS has provided support for vaccine development and/or distribution with AstraZeneca, Johnson \& Johnson ad Sanofi/GlaxoSmithKline [44].

Both Pfizer and Moderna "expect to profit, and not to provide their [vaccine] products at cost" [38]. Under the OWS contracts, they cannot charge for the hundreds of millions of vaccine doses they turn over to the federal government. Aside from profit Pfizer has made in its contract for distribution and Moderna has made in its contracts for development and distribution, these companies can profit from sales in other countries or in the U.S. after their contracts expire. In addition to the subsidies these companies obtained under OWS, the decades of underlying basic research in government laboratories, notably at NIH, has been paid for by U.S. taxpayers.

One sour note in Operation Warp Speed is a potential conflict of interest of its chief adviser, Moncef Slaoui. In his disclosure for the paper on OWS that he coauthored [35] he declared he was "formerly on the board of directors of Moderna, one of the companies with a selected vaccine for Covid19" [35]. The day before President Trump announced Slaoui's appointment as OWS's chief adviser, he resigned from Moderna's board [49].

\section{The future}

The United States and many other countries are into their third surge of Covid-19 cases, which in most countries, exceeds the previous two surges in number of new cases and deaths. Despite over 1 million SARS-CoV-2 lab tests currently being performed per day in the U.S. [50], the epidemic continues to increase exponentially [1].

China and New Zealand, two of the countries mentioned earlier that had curbed their pandemics, have not yet had a second surge [1]. Their continued successes can be attributed primarily to testing, contact tracing, and quarantine, all done under government initiative. In the U.S. most tests are performed in commercial laboratories that have little incentive for contact tracing. With a public increasingly impoverished by unemployment and impatient at being cooped up, the public may be less receptive to contact tracing and quarantine than would have been the case at the start of the pandemic. What, then, are the prospects for reversing the increase in Covid-19 cases in the U.S.?

The remarkable success of Operation Warp Speed in making two efficacious SARS-CoV-2 vaccines available to high risk groups in record time offers a glimmer of hope. What at first seems even more astounding is that President Trump's government became not only sole owner of the vaccines but also the single payer for them, replacing health insurers and out-of-pocket payers. This is not so astounding when we realize that the recipient of this government largesse is the pharmaceutical industry whose rate of profit is higher than other industries [51].

For reasons already stated, the effectiveness of these vaccines and others may not be as great as expected from the phase 3 clinical trials. The hurdles already encountered in distributing the vaccines, plus the persistent suspicions many people have about the vaccines, will reduce the rate at which people become immune. In addition, some vaccine recipients may get a false sense of security about getting infected from the large unvaccinated portion of the population and will no longer wear masks or safe distance. We still don't know whether the vaccine prevents vaccinees from acquiring asymptomatic infections that they can communicate to others who are not immune.

Over the past 9 months President Trump and his administration have issued contradictory information on how the pandemic can be curbed. Often they have been at odds with state governments, leaving the public confused about what to do. When President-elect Biden takes office on 20 January 2021, the messages from the federal and many state governments will be consistent, but until the Congress passes, and the president signs, legislation authorizing sufficient funding for massive contact tracing and quarantine, the coming winter surge on top of the autumn one will not be contained. Making matters worse, the number of people living in poverty, among whom people of color comprise a disproportionate share, rose by 8 million between May and October in the U.S. [52], and will continue to grow, increasing the number of people most vulnerable to Covid-19 infections.

Without Congressional action, the 13 million people receiving payments under programs enacted by Congress last spring will lose their remaining unemployment 
benefits when they expire at the end of 2020, as will a partial federal eviction moratorium [53]. As of 18 December, Congress has failed to agree on a relief package (although negotiations are ongoing) and aid to states to expand contact tracing. Unless both Democratic candidates for Senate from Georgia win in the runoff election on 5 January, President Biden will have a difficult time getting such legislation passed.

For the long term, negative and positive lessons can be learned from the Trump administration's management of the Covid-19 crisis. Reducing the authority and capability of CDC and state and local health departments to test for SARS-CoV-2 and leaving it to commercial laboratories and manufacturers with only a modicum of federal regulation, was a disaster. On the other hand, the strong role federal government played in laying down stringent requirements for clinical trials that pharmaceutical companies had to meet before they could make vaccines available to the public, resulted in efficacious vaccines in record time. (Continued monitoring for adverse events is needed to assure safety.) These lessons will help future governments prepare for the inevitable occurrence of the next pandemic.

\section{Menlo Park CA, USA}

18 December 2020

\section{Acknowledgements}

I am grateful to Steven Holtzman and Juan Gervas for helpful suggestions.

\section{Author's contributions}

The author researched, wrote, read, and approved the final manscript.

\section{Funding}

No funding was used in the collection of information or the preparation of the manuscript.

\section{Availability of data and materials \\ N/A}

\section{Ethics approval and consent to participate}

N/A - This is not a clinical study. No subjects participated.

\section{Consent for publication}

N/A

\section{Competing interests}

I have no competing interests.

Received: 7 December 2020 Accepted: 9 December 2020 Published online: 04 January 2021

\section{References}

1. Worldometer. Covid-19 coronavirus pandemic, reported cases and deaths by country, territory, or conveyance. 2020. https://www.worldometers.info/ coronavirus/?fbclid=IwAR0zkpRD_zQZb4UkziGI_Xvv75s5Q3eynf7f9pOspxGbgHbe7OqpGBriBI. Accessed 16 Dec 2020.

2. Bureau of Labor Statistics. The employment situation-November 2020. 2020. https:/www.bls.gov/news.release/pdf/empsit.pdf. Accessed 16 Dec 2020

3. Watson C, Cicero A, Blumenstock J, Fraser M. A national plan to enable comprehensive COVID-19 case finding and contact tracing in the US: Center for Health Security, Johns Hopkins Bloomberg School of Public Health; Association of State and Territorial Health Officers; 2020. https:// www.centerforhealthsecurity.org/our-work/pubs_archive/pubs-pdfs/2020/2 00410-national-plan-to-contact-tracing.pdf. Accessed 5 Nov 2020.

4. Williams MA. Shrinking public health budgets shrink public heath responses 2020. https://www.bostonglobe.com/2020/03/03/opinion/shrinking-publichealth-budgets-shrink-public-health-responses/. Accessed 6 Nov 2020.

5. Reuters staff. Partly false claim: Trump fired entire pandemic response team in 2018. 2020. https://www.reuters.com/article/uk-factcheck-trump-firedpandemic-team/partly-false-claim-trump-fired-pandemic-response-team-in-2 018-idUSKBN21C32M. Accessed 6 Nov 2020

6. Witt JF. Republican judges are quietly upending public health laws. 2020. https://www.nytimes.com/2020/10/15/opinion/coronavirus-health-courts. html. Accessed 6 Nov 2020.

7. Hinton DM. FDA letter to Redfield, RR III. Waiver of certain requirements. 2020. https://www.fda.gov/media/134919/download. Accessed 6 Nov 2020.

8. Hahn SM, Coronavirus (COVID-19) Update: FDE expedites review of diagnostic tests to combat COVID-19. 2020. https://www.fda.gov/newsevents/press-announcements/coronavirus-covid-19-update-fda-expeditesreview-diagnostic-tests-combat-covid-19. Accessed 7 Nov 2020.

9. Summary of the Findings of the Immediate Office of the General Counsel's investigation regarding CDC's production of COVID-19 test kits. 2020. https://www.washingtonpost.com/context/summary-of-the-findings-of-theimmediate-office-of-the-general-counsel-s-investigation-regarding-cdc-sproduction-of-covid-19-test-kits/a750fbf7-9a4f-4062-8fcc-c6cf42600578/?itid= Ik_interstitial_manual_7. Accessed 7 Nov 2020.

10. Wilman D. Contamination at CDC lab delayed rollout of coronavirus tests. 2020. https://www.washingtonpost.com/investigations/contamination-atcdc-lab-delayed-rollout-of-coronavirus-tests/2020/04/18/fd7d3824-7139-11 ea-aa80-c2470c6b2034_story.html. Accessed 7 Nov 2020.

11. FDA. In vitro diagnostics EUAs. 2020. https://www.fda.gov/medical-devices/ coronavirus-disease-2019-covid-19-emergency-use-authorizations-medicaldevices/vitro-diagnostics-euas\#individual-molecular. Accessed 7 Nov 2020.

12. Rodgers B, Albeerty E. Utah tech CEO behind TestUtah showed early interest in malaria drugs. 2020. https://www.sltrib.com/news/2020/05/02/ utah-tech-ceo-behind/. Accessed 7 Nov 2020

13. Baird RP, How Utah's tech industry tried to disrupt corona virus testing. 2020. https://www.newyorker.com/tech/annals-of-technology/how-utahstech-industry-tried-to-disrupt-coronavirus-testing. Accessed 7 Nov 2020.

14. Weiland N. 'Like a hand grasping': Trump appointees describe the crushing of the C.D.C. 2020. https://www.nytimes.com/2020/12/16/us/politics/cdctrump.html?referringSource=articleShare. Accessed 16 Dec 2020.

15. Rowland C, Cenziper D, Rein L. White House sidestepped FDA to distribute hydroxychloroquine to pharmacies, documents show. Trump touted the pills to treat covid-19. 2020. https://www.washingtonpost.com/business/202 0/10/31/trump-hydroxychloroquine-stockpile-pharmacies/. Accessed 7 Nov 2020.

16. Rowland C. Remdesivir may not cure coronavirus but it's on track to make billions for Gilead. 2020. https://www.washingtonpost.com/business/2020/ 09/30/remdesivir-drug-coronavirus-gilead/. Accessed 7 Nov 2020.

17. Cohen J, Kupferschmidt K. 'A very, very bad look' for remdesivir. $2020 \mathrm{https} / /$ science.sciencemag.org/content/370/6517/642. Accessed 8 Nov 2020.

18. Mahase E. Covid-19: FDA authorizes neutralizing antibody bamlanivimab for non-admitted patients. 2020. https://www.bmj.com/content/371/bmj. m4425. Accessed 11 Nov 2020.

19. Madrigal AC, Meyer R. Private labs are fueling a new corona virus testing crisis. 2020. https://www.theatlantic.com/health/archive/2020/03/nextcovid-19-testing-crisis/609193/?utm_source=Global+Health+NOW+Main+ List\&utm_campaign=246a4a9146-EMAIL_CAMPAIGN_2020_04_01_01_16 \&utm_medium=email\&utm_term=0_8d0d062dbd-246a4a9146-3095961. Accessed 8 Nov 2020.

20. Stein R. Study raises questions about false negatives from quick Covid-19 test. 2020. https://www.npr.org/sections/health-shots/2020/04/21/8387942 81/study-raises-questions-about-false-negatives-from-quick-covid-19test?utm_source=Global+Health+NOW+Main+List\&utm_campaign=83a916 f5a2-EMAIL_CAMPAIGN_2020_04_21_12_33\&utm_medium=email\&utm_ term $=0 \_8 d 0 \mathrm{~d} 062 \mathrm{dbd}-83 \mathrm{a} 916 f 5 \mathrm{a} 2-3095961 \mathrm{de}$. Accessed 8 Nov 2020.

21. FDA. SARS-CoV-2 reference panel; comparative data. 2020. https://www.fda. gov/medical-devices/coronavirus-covid-19-and-medical-devices/sars-cov-2reference-panel-comparative-data. Accessed 8 Nov 2020.

22. Wan W. How do home tests for coronavirus work? Where can I get one? 16 2020. https://www.washingtonpost.com/health/2020/12/16/coronavirushome-test-rapid/. Accessed 17 Dec 2020. 
23. Chwe H, Quintana A, Lazer D et al. The states of the nation: a 50-state covid-19 survey report \#17: covid-19 test result times. 2020 http://www. kateto.net/covid19/COVID19\%20CONSORTIUM\%20REPORT\%2017\%2 OTESTING\%200CT\%202020.pdf. Accessed 8 Nov 2020.

24. Butler D, Hamburger T, Sun LH, Kaplan S. White House could have traced and contained its coronavirus outbreak. It chose not to. 2020. https://www. washingtonpost.com/health/2020/10/28/white-house-covid-outbreakinvestigation-contact-tracing/. Accessed 8 Nov 2020.

25. Kamisar B, Holzberg M. Poll: Coronavirus fatigue may be setting in as more see pandemic as economic crisis. 2020. https://www.nbcnews.com/ politics/2020-election/poll-coronavirus-fatigue-may-be-setting-more-seepandemic-economic-n1239473. Accessed 8 Nov 2020.

26. Miao H. Here's what matters most to voters in the 2020 election, according to exit polls. 2020. https://www.cnbc.com/2020/11/03/exit-polls-heres-whatmattered-most-to-voters-in-the-2020-election.html. Accessed 9 Nov 2020.

27. Fisher KA, Barile JP, Guerin RJ, et al. Factors associated with cloth face covering use among adults during the COVID-19 pandemic - United States, April and May 2020. MMWR Morb Mortal Wkly Rep. 2020;69:933-7. https://doi.org/10.15585/mmwr.mm6928e3 Accessed 7 Dec 2020

28. Jay J, Bor J, Nsoesie EO et al. Neighbourhood income and physical distancing during the COVID-19 pandemic in the United States. 2020. https://www.nature.com/articles/s41562-020-00998-2. Accessed 11 Nov 2020.

29. NAACP. Criminal justice fact sheet; criminal justice system: corrections. No date. www.naacp.org/criminal-justice-fact-sheet. Accessed 9 Nov 2020.

30. Watson C, Warmbrod KL, Vahey RA, et al. COVID-19 and the US criminal justice system: evidence for public health measures to reduce risk: Center for Health Security and Center for Public Health and Human Rights, Johns Hopkins Bloomberg School of Public Health; 2020. https://www. centerforhealthsecurity.org/our-work/pubs_archive/pubs-pdfs/2020/20201 015-covid-19-criminal-justice-system.pdf. Accessed 5 Nov 2020.

31. Kurani N, Pollitz K, Cotliar D Shanosky N, Cox C. COVID-19 test prices and payment policy, 2020, https://www.healthsystemtracker.org/brief/covid-19test-prices-and-payment-policy/. Accessed 27 Oct 2020.

32. McNicholas C, Poydock M. Who are essential workers? A comprehensive look at their wages, demographics, and unionization rates. 2020. https:// www.epi.org/blog/who-are-essential-workers-a-comprehensive-look-at-theirwages-demographics-and-unionization-rates/. Accessed 9 Nov 2020.

33. Press E, Trump's Labor Secretary is a wrecking ball aimed at workers. 2020. https://www.newyorker.com/magazine/2020/10/26/trumps-labor-secretaryis-a-wrecking-ball-aimed-at-workers. Accessed 9 Nov 2020.

34. Statista. Real average hourly earnings for all employees in the United States from October 2019 to October 2020. 2020. https://www.statista.com/ statistics/216259/monthly-real-average-hourly-earnings-for-all-employees-inthe-us/. Accessed 13 Nov 2020.

35. Cooper A. US billionaires saw their net worth rise by almost $\$ 1$ trillion between March and October: Markets Insider; 2020. https://markets. businessinsider.com/news/stocks/us-billionaires-wealth-rises-trillion-duringpandemic-amount-grow-bezos-2020-10-1029698554\#. Accessed 9 November 2020.

36. MacMillan D, Whoriskey P, O'Connell J. America's biggest companies are flourishing during the pandemic and putting thousands of people out of work. 2020. https://www.washingtonpost.com/graphics/2020/business/50biggest-companies-coronavirus-layoffs/?itid=sf_business. Accessed $16 \mathrm{Dec}$ 2020.

37. Slaoui M, Hepburn M. Developing safe and effective Covid vaccines Operation Warp Speed's strategy and approach. 2020. https://www.nejm. org/doi/full/10.1056/NEJMp2027405. Accessed 16 Dec 2020.

38. Johnson CY. Pfizer's corona virus vaccine is more than 90 percent effective in first analysis, company reports. 2020. https://www.washingtonpost.com/ health/2020/11/09/pfizer-coronavirus-vaccine-effective/. Accessed 16 Dec 2020.

39. Grady D. Early data show Moderna's Coronavirus vaccine is $94.5 \%$ effective. 2020. https://www.nytimes.com/2020/11/16/health/Covid-moderna-vaccine. html?referringSource=articleShare. Accessed 16 Dec 2020.

40. FDA. Emergency use authorization for vaccines to prevent COVID-19: guidance for industry. 2020. https://www.fda.gov/media/142749/download. Accessed 16 Dec 2020

41. FDA. Charter of the Vaccines and Related Biological Products Advisory Committee https://www.fda.gov/advisory-committees/vaccines-and-related- biological-products-advisory-committee/charter-vaccines-and-relatedbiological-products-advisory-committee. Accessed 11 Nov 2020.

42. Hodgson SH, Mansatta K, Mallett G, Harris V, Emary KRW, Pollard AJ. What defines an efficacious COVID-19 vaccine? A review of the challenges assessing the clinical efficacy of vaccines against SARS-CoV-2. Lancet Infect Dis. 2020. https://doi.org/10.1016/S1473-3099(20)30773-8 Accessed 31 Oct 2020.

43. Silverman E. STAT-Harris Poll: the share of Americans interested in getting Covid-19 vaccine as soon as possible is dropping. 2020. https://www. statnews.com/pharmalot/2020/10/19/covid19-coronavirus-pandemicvaccine-racial-disparities/. Accessed 31 Oct 2020

44. HHS.gov. Fact Sheet: explaining Operation Warp Speed. 2020. https://www. hhs.gov/coronavirus/explaining-operation-warp-speed/index.html. Accessed 16 Dec 2020.

45. Stanley-Becker I, Abutaleb Y, Sun LH, Dawsey J. States report confusion as government reduces vaccine shipments, while Pfizer says it has 'millions' of unclaimed doses. 2020. https://www.washingtonpost.com/health/2020/12/1 7/pfizer-vaccine-supply-states/?utm_campaign=wp_todays_headlines\&utm_ medium $=$ email\&utm_source $=$ newsletter\&wpisrc=nl_headlines. Accessed 18 Dec 2020.

46. Goldhill O. 'We're being left behind': rural hospitals can't afford ultra-cold freezers to store the leading Covid-19 vaccine. 2020. https://www.statnews. com/2020/11/11/rural-hospitals-cant-afford-freezers-to-store-pfizer-covid19vaccine/. Accessed 11 Nov 2020.

47. Johnson CY, Achenbach J. FDA investigating rare allergic reactions to Pfizer coronavirus vaccine, but says rollout will continue. 2020. https://www. washingtonpost.com/health/covid-vaccine-allergic-reactions/2020/12/17/a84 90340-409d-11eb-8bc0-ae155bee4aff_story.html. Accessed 18 Dec 2020.

48. Wise MJ, Viray M, Sejvar JJ. Guillain-Barré syndrome during the 2009-2010 H1N1 influenza vaccination campaign: population-based surveillance among 45 million Americans. Am J Epidemiol. 2012;175(11):1110-9 https:// www.ncbi.nlm.nih.gov/pmc/articles/PMC3888111/. Accessed 16 Dec 2020.

49. Pradhan R. How Pharma cash colors Operation Warp Speed. 2020. https:// news.yahoo.com/pharma-cash-colors-operation-warp-085501646.html. Accessed 5 Dec 2020

50. Johns Hopkins Coronavirus Resource Center. Testing from the COVID Tracking Project. 2020. https://coronavirus.jhu.edu/testing/individual-states. Accessed 11 Nov 2020.

51. Ledley FD, McCoy SS, Vaughan G. Profitability of large pharmaceutical companies compared with other large public companies. 2020. https:// jamanetwork.com/journals/jama/fullarticle/2762308. Accessed 17 Dec 2020.

52. DeParle J. 8 million have slipped into poverty since may as Federal Aid has dried up. 2020. https://www.nytimes.com/2020/10/15/us/politics/federal-aidpoverty-levels.html. Accessed 11 Nov 2020.

53. Casselman B. Millions face loss of jobless aid: 'Without it, I'm dead in the water'. 2020. https://www.nytimes.com/2020/11/11/business/economy/ unemployment-benefits-cutoff.html?referringSource=articleShare. Accessed 11 Nov 2020.

\section{Publisher's Note}

Springer Nature remains neutral with regard to jurisdictional claims in published maps and institutional affiliations.

Ready to submit your research? Choose BMC and benefit from:

- fast, convenient online submission

- thorough peer review by experienced researchers in your field

- rapid publication on acceptance

- support for research data, including large and complex data types

- gold Open Access which fosters wider collaboration and increased citations

- maximum visibility for your research: over $100 \mathrm{M}$ website views per year

At $\mathrm{BMC}$, research is always in progress.

Learn more biomedcentral.com/submission 